\title{
Efek Color Retention Agent pada Mi Basah dengan Pewarna Alami Cabai Merah (Capsicum Annuum L.) pada Karakteristik Fisikokimia
}

\section{(The Effect of Color Retention Agent on Wet Noodles with Red Chili (Capsicum Annuum L.) Natural Dyes on Its Physicochemical Characteristics)}

\author{
Alyarahma Nur Aisya*, Siti Susanti, Bhakti Etza Setiani \\ (Diterima Juli 2019/Disetujui Desember 2020)
}

\begin{abstract}
ABSTRAK
Sudah banyak terdapat inovasi olahan mi basah dengan variasi warna. Inovasi pengolahan mi basah tersebut dapat diolah dengan pewarna alami, seperti pewarna dari buah atau sayur. Sari cabai merah dapat digunakan sebagai pewarna alami mi basah. Pewarna alami mudah larut dalam proses perebusan sehingga untuk mempertahankan warnanya, digunakan color retention agents yang ditambahkan dalam proses pengolahannya. Penelitian ini bertujuan untuk mengatahui pengaruh penambahan color retention agents pada karakteristik fisikokimia produk mi basah yang diwarnai dengan pewarna alami cabai merah, yang meliputi kadar air, ketahanan warna, tekstur, dan kandungan vitamin C. Metode yang digunakan yaitu Rancangan Acak Lengkap (RAL) yang menerapkan 5 perlakuan penggunaan jenis color retention agent dengan 4 kali pengulangan. Perlakuan yang diterapkan ialah T0: tanpa penambahan color retention agent, T1: asam askorbat $\left(\mathrm{C}_{6} \mathrm{H}_{8} \mathrm{O}_{6}\right)$, T2: asam sitrat $\left(\mathrm{C}_{6} \mathrm{H}_{8} \mathrm{O}_{7}\right)$, T3: magnesium hidroksida $\left(\mathrm{Mg}(\mathrm{OH})_{2}\right)$, dan $\mathrm{T4}$ : magnesium karbonat $\left(\mathrm{MgCO}_{3}\right)$. Data hasil pengujian diianalisis menggunakan Analysis of Variance (ANOVA), jika terdapat pengaruh nyata pada taraf signifikansi $5 \%$ maka dilanjutkan dengan Uji Wilayah Ganda Duncan untuk mengetahui perbedaan antarperlakuan. Semua analisis data dihitung dengan bantuan program SPSS 21.0 for windows. Data hasil pengujian kandungan vitamin C dianalisis dengan Microsoft Excel melalui analisa Grafik. Hasil yang diperoleh yaitu penambahan color retention agent pada mi basah dengan pewarna alami dari cabai memberikan pengaruh yang nyata pada ketahanan warna, kadar air, tekstur, dan kandungan vitamin $\mathrm{C}$ mi basah. Mi basah T4 merupakan mi basah perlakuan terbaik dalam mempertahankan warna merah dengan karakteristik fisik sesuai SNI.
\end{abstract}

Kata kunci: cabai merah, color retention agents, mi basah

\section{ABSTRACT}

There are many innovations in wet noodle processing with color variations. One of wet noodle processing innovations is the use of natural dyes such as fruit or vegetable dyes. The essence of red chilies can be used as a natural dye for wet noodles. Natural dyes dissolve easily during the boiling process, therefore color retention agents can be added in the processing and expected to be able to retain the red color of chilies in wet noodles. This study aims to determine the effect of adding color retention agents on physicochemical characteristics, namely moisture content, color resistance, texture, and vitamin $C$ content in wet noodles. The method used in this study was a completely randomized design (CRD) with 5 treatments of color retention agents each with 4 repetitions. The treatments applied were T0: without the addition of a color retention agent, T1: ascorbic acid $\left(\mathrm{C}_{6} \mathrm{H}_{8} \mathrm{O}_{6}\right)$, $\mathrm{T}_{2}$ : citric acid $\left(\mathrm{C}_{6} \mathrm{H}_{8} \mathrm{O}_{7}\right)$, T3: magnesium hydroxide $\left(\mathrm{Mg}\left(\mathrm{OH}_{2}\right)\right)$, and T4: magnesium carbonate $\left(\mathrm{MgCO}_{3}\right)$. The test results were analyzed using Analysis of Variance (ANOVA) and if there is a significant effect at the $5 \%$ significance level, then proceed with the Duncan Multiple Region Test to determine the differences between treatments. All data analyses were calculated by using a computer program SPSS 21.0 for windows. Data from the test for vitamin C content were analyzed using Microsoft Excel through graphical analysis. The results is addition of color retention agent treatment to wet noodles with natural dyes from chilies had a significant effect on the color resistance, moisture content, texture, and vitamin $\mathrm{C}$ content of wet noodles. T4 wet noodle is the best wet noodle treatment in maintaining the red color with the physical characteristics according to SNI.

Keywords: color retention agents, noodles, red chili

\section{PENDAHULUAN}

Mi basah merupakan salah satu olahan pangan dari tepung terigu yang banyak digemari masyarakat Program Studi Teknologi Pangan, Fakultas Peternakan dan Pertanian, Universitas Diponegoro, Jl. Prof. Soedarto, SH., Tembalang, Semarang 50275

*Penulis Korespondensi: Email: alyarahmanura@gmail.com
Indonesia dari berbagai kalangan. Dewasa ini, sudah banyak inovasi olahan mi basah dengan variasi warna. Inovasi pengolahan mi basah tersebut dapat dilakukan dengan penggunaan pewarna sinetis maupun pewarna alami, seperti pewarna dari buah atau sayur. Dalam pemakaian pewarna sintetis, terdapat beberapa produsen yang bahkan menggunakan pewarna buatan yang sebenarnya tidak diperbolehkan dalam olahan 
pangan karena memiliki efek karsinogenik berbahaya jika dikonsumsi manusia (Manurung 2012). Salah satu alasan penggunaan pewarna tekstil ialah pertimbangan harga yang relatif lebih murah dan penggunaannya yang mudah, menghasilkan warna yang lebih menarik dan lebih tidak mudah pudar pada saat pengolahannya. Penelitian mengenai mi basah berwarna ini sudah banyak dilakukan, di antaranya terdapat penelitian yang menggunakan pewarna alami dari ekstrak kulit buah naga dengan perlakuan variasi volume larutan ekstrak buah naga salah satunya pada tingkat kecerahan mi (Oktiarni et al. 2012). Berdasarkan penelitian tersebut diperoleh hasil bahwa warna merah dari ekstrak buah naga memudar setelah mi basah diberi perlakuan perebusan maupun pengukusan akibat pemanasan yang merusak gugus kromofor pigmen zat warna kulit buah naga sehingga warna memucat. Penelitian lain mengenai mi basah ialah pembuatan mi basah menggunakan cabai merah sebagai pewarna alami dengan analisis parameter uji organoleptik dan kandungan vitamin C (Bahri 2012). Berdasarkan penelitian yang telah dilakukan tersebut, diketahui bahwa belum dilakukan uji dan analisis pada ketahanan pewarna cabai pada mi setelah mengalami proses perebusan. Pengembangan yang dapat dilakukan dari penelitan-penelitian tersebut salah satunya adalah penambahan color retention agent yang mampu mempertahankan warna mi, terutama pada saat mi diberi perlakuan perebusan.

Oleh karena itu, dalam penelitian ini digunakan pewarna alami cabai merah dengan penambahan color retention agent supaya menghasilkan warna mi yang tidak pudar pada saat pengolahannya. Penelitian dilakukan untuk mengevaluasi pengaruh color retention agent pada kadar air, ketahanan warna, kandungan vitamin $\mathrm{C}$, dan tekstur mi basah yang diwarnai dengan pewarna alami cabai merah.

\section{METODE PENELITIAN}

Penelitian dilaksanakan pada bulan Mei-Juni 2019 di Laboratorium Kimia dan Gizi Pangan dan Laboratorium Terpadu, Universitas Diponegoro, Semarang.

Bahan yang digunakan dalam penelitian ini ialah tepung terigu Cakra Kembar (Bogasari), telur ayam, cabai merah varietas landung, air mineral, garam, natrium karbonat/soda abu, asam askorbat, asam sitrat, magnesium hidroksida, dan magnesium karbonat. Bahan-bahan dan takaran dalam pembuatan mi basah disajikan pada Tabel 1. Alat yang digunakan adalah pasta maker (ATLAS), baskom, blender, penyaring, gelas ukur, mangkuk, sendok, pisau, neraca analitik, erlenmeyer, texture analyzer, HPLC, oven, desikator, cawan porselen, mortar, dan color reader.

Setiap $500 \mathrm{~g}$ tepung terigu dicampur dengan 1,3 gram soda abu, yang sesuai dengan ketentuan BPOM Nomor 11 Tahun 2013 bahwa batas maksimum penggunaan natrium karbonat atau soda abu adalah $2600 \mathrm{mg} / \mathrm{kg}$. Pengolahan mi basah secara garis besar terdiri atas proses pembuatan sari cabai, pencampuran sari cabai dengan soda abu, garam, dan serbuk color retention agent serta pengulenan adonan mi basah. Proses awal pengolahan mi basah diawali dengan pembuatan sari cabai. Sari cabai dihasilkan dari 300 gram daging cabai merah yang sudah dipisahkan dari bijinya lalu dicuci bersih. Daging cabai kemudian dilarutkan dengan $100 \mathrm{ml}$ aquades dan dihaluskan dengan blender, lalu disaring. Hasil saringan ini merupakan sari cabai yang digunakan untuk mencampur adonan mi basah. Dalam penelitian ini digunakan sebanyak $225 \mathrm{ml}$ sari cabai. Langkah kedua ialah pelarutan bahan kering dalam sari cabai. Sebanyak $1,3 \mathrm{~g}$ soda abu, $2 \mathrm{~g}$ garam, dan $1,3 \mathrm{~g}$ serbuk color retention agent ditambahkan ke dalam $225 \mathrm{ml}$ sari

Tabel 1 Formulasi mi basah

\begin{tabular}{|c|c|c|c|c|c|}
\hline \multirow{2}{*}{ Bahan yang digunakan } & \multicolumn{5}{|c|}{ Perlakuan } \\
\hline & T0 (g) & $\mathrm{T} 1 \mathrm{~g})$ & $\mathrm{T} 2(\mathrm{~g})$ & T3 (g) & $\mathrm{T} 4(\mathrm{~g})$ \\
\hline Tepung terigu & 500 & 500 & 500 & 500 & 500 \\
\hline \multirow{2}{*}{$\begin{array}{l}\text { Telur ayam } \\
\text { Soda abu }\left(\mathrm{Na}_{2} \mathrm{CO}_{3}\right)\end{array}$} & 50 & 50 & 50 & 50 & 50 \\
\hline & 1,3 & 1,3 & 1,3 & 1,3 & 1,3 \\
\hline Garam & 2 & 2 & 2 & 2 & 2 \\
\hline Sari Cabai & 225 & 225 & 225 & 225 & 225 \\
\hline Asam askorbat & - & 1,3 & - & - & - \\
\hline Asam sitrat & - & - & 1,3 & - & - \\
\hline $\mathrm{Mg}(\mathrm{OH})_{2}$ & - & - & - & 1,3 & - \\
\hline $\mathrm{MgCO}_{3}$ & - & - & - & - & 1,3 \\
\hline $\begin{array}{r}\text { eterangan: }{ }^{*} \text { To adalah } \\
\text { basah deng } \\
\text { T2 adalah } \\
\text { retention ag } \\
\text { sebagai col } \\
\text { MgCO3 seb }\end{array}$ & $\begin{array}{l}\text { arn kont } \\
\text { arna ala } \\
\text { adalal } \\
\text { tion ag } \\
\text { lor retes }\end{array}$ & $\begin{array}{l}\text { pewarn } \\
\text { erah de } \\
\text { a alami } \\
\text { denga } \\
\text { lah mi b } \\
{ }^{*} \text { Sari c }\end{array}$ & $\begin{array}{l}\text { bai mer } \\
\text { mbahan } \\
\text { rah der } \\
\text { alami } \\
\text { an pew } \\
\text { ai meral }\end{array}$ & $\begin{array}{l}\text { lor rete } \\
\text { bat seb } \\
\text { bahan a } \\
\text { denga } \\
\text { abai me } \\
\text { (g) : } 10\end{array}$ & $\begin{array}{l}\text { T1 ad } \\
\text { etentior } \\
\text { sebaga } \\
\text { han M } \\
\text { penan }\end{array}$ \\
\hline
\end{tabular}


cabai yang sudah disiapkan, kemudian diaduk hingga bahan kering cukup larut. Selanjutnya, pengulenan adonan mi. Sebanyak $500 \mathrm{~g}$ tepung terigu dituang ke dalam baskom lalu dicampur dengan $50 \mathrm{~g}$ telur ayam hingga merata. Larutan bahan-bahan kering dalam sari cabai kemudian dituangkan ke dalam campuran tepung terigu dengan telur untuk menghidrasi adonan, dan sari cabai dituang secara sedikit demi sedikit, sembari dilakukan pengulenan adonan hingga kalis (Bahri 2012).

Adonan yang sudah kalis didiamkan terlebih dahulu selama \pm 15 menit agar penyebaran air dan jaringan gluten terbentuk secara merata. Setelah didiamkan selama \pm 15 menit, adonan dipotong menjadi beberapa bagian dengan tiap bagian sebesar $\pm 25 \mathrm{~g}$, adonan kemudian dipipihkan dengan roller lalu digiling atau dipotong dengan pasta maker atau slitter. Pemipihan adonan ini juga bertujuan untuk memudahkan proses pemotongan menjadi untaian mi. Pada pengujian ketahanan warna, tekstur, dan kandungan vitamin $\mathrm{C}$, untaian mi basah harus direbus terlebih dahulu. $\mathrm{Mi}$ basah direbus dalam air mendidih pada suhu $\pm 100^{\circ} \mathrm{C}$ selama 3-5 menit, kemudian mi ditiriskan untuk dilakukan pengujian parameter.

\section{Pengolahan dan Analisis Data}

Data hasil pengujian kadar air, intensitas warna, dan tekstur dengan menggunakan Analysis of Variance (ANOVA) dan jika terdapat pengaruh nyata pada taraf signifikansi $5 \%$ maka dilanjutkan dengan $U j i$ Wilayah Ganda Duncan untuk mengetahui perbedaan antarperlakuan. Semua analisis data dihitung dengan bantuan komputer program SPSS 21.0 for windows. Data hasil pengujian kandungan vitamin $C$ dianalisis dengan Microsoft Excel melalui analisa grafik.

\section{Pengujian Variabel}

\section{- Kadar air (AOAC, 2005)}

Prinsip metode ini adalah mengeringkan sampel bahan dalam oven bersuhu $100-105^{\circ} \mathrm{C}$ hingga bobot konstan dan perbandingan antara bobot sampel kering dengan bobot sampel awal dihitung sebagai total padatan. Prosedur dan perhitungan total padatan metode pengeringan oven adalah sebagai berikut: cawan porselin diberi kode sesuai sampel dan dipanaskan dalam oven pada suhu $100-105^{\circ} \mathrm{C}$ selama 1 jam, kemudian cawan porselin dimasukan dalam desikator selama 15 menit lalu ditimbang $(A)$, sampel ditimbang sebanyak $2 \mathrm{~g}$ (B) di dalam cawan porselin yang sudah diketahui bobotnya, selanjutnya sampel dioven pada suhu $100-105^{\circ} \mathrm{C}$ selama 4 jam, dimasukkan desikator lalu ditimbang, kemudian dioven kembali selama 1 jam, dimasukkan desikator dan ditimbang kembali hingga konstan (C). Bobot dianggap konstan apabila selisih penimbangan tidak melebihi 0,2 $\mathrm{mg}$.

Total padatan dapat dihitung dengan rumus sebagai berikut:

$$
\text { Kadar Air }=\frac{C-A}{B} \times 100 \%
$$

\section{- Ketahanan warna}

Pengujian ketahanan warna mi ini dilakukan sebanyak dua kali, yaitu sebelum dan setelah mi mengalami perebusan. Pengujian ketahanan warna dilakukan melalui penilaian warna mi basah dengan metode color reader. Analisis dengan color reader akan disajikan dalam nilai $\mathrm{L}^{*}$, $\mathrm{a}^{*}$, dan $\mathrm{b}^{*}$ di mana nilai $L^{*}$ menunjukkan derajat kecerahan, nilai $a^{*}$ adalah nilai untuk warna merah, dan $b^{*}$ untuk menunjukkan warna kuning (Retnowati \& Kusnadi 2014).

Analisis ketahanan warna dilakukan pada nilai $L^{*}$ dan $\mathrm{a}^{*} \mathrm{mi}$ basah, serta tidak dilakukan analisa pada nilai $b^{*}$ mi basah. Hal ini disebabkan karena nilai $b^{*}$ menyatakan warna hijau ke kuning, sementara warna kuning dalam mi basah data mengindikasikan warna merah dari karotenoid yang memudar. Warna merah pigmen karotenoid yang memudar ini sudah dapat dinyatakan melalui nilai $L^{*}$ mi basah karena nilai $L^{*}$ menunjukkan kecerahan atau pudarnya warna merah dari karotenoid dalam mi basah. Indikator pemudaran warna merah mi basah adalah selisih dari nilai $L^{*}$ dan $a^{*}$ mi basah setelah perebusan dengan nilai $L^{*}$ dan $a^{*}$ mi basah sebelum perebusan. Oleh karenanya, analisis nilai $L^{*}$ dan $a^{*}$ mi basah dilakukan pada mi basah sebelum serta setelah proses perebusan. Metode ini dilakukan dengan menggunakan color reader dari sistem ios. Sampel diletakkan di dalam kotak yang diberi penerangan. Pembacaan nilai $L^{*}, a^{*}$, dan $b^{*}$ dilakukan melalui kamera dari perangkat ios yang membidik titik lokasi warna sampel, besaran nilainya akan ditampilkan pada aplikasi di perangkat. Rumus ketahaanan warna:

\section{$\Delta \mathrm{L}^{*} / \mathrm{a}^{*}$}

Keterangan:

$\Delta \mathrm{L}^{*}=\mathrm{L}^{*}$ akhir $-\mathrm{L}^{*}$ awal

$\Delta \mathrm{a}^{*}=\mathrm{a}^{*}$ akhir $-\mathrm{a}^{*}$ awal

\section{- Analisa tekstur}

Analisis tekstur dilakukan dengan prinsip TPA atau Texture Profile Analysis. Analisis tekstur mi dilakukan dengan tujuan untuk mengetahui pengaruh setiap perlakuan pada karakteristik tekstur mi basah. Analisis tekstur dilakukan pada mi basah perlakuan T0, T1, T2, T3 dan T4 yang sudah direbus dalam air mendidih pada suhu $\pm 100^{\circ} \mathrm{C}$ selama $3-5$ menit (Sumardana et al. 2017). Analisis tekstur dilakukan dengan menggunakan alat texture analyzer (Engelen 2017). Analisis tekstur mi basah meliputi kekenyalan dan kelengketan mi basah.

Analisis kekenyalan dan kelengketan dilakukan dengan alat texture analyzer. Langkah awalnya ialah preparasi sampel mi basah setelah direbus lalu ditiriskan, texture analyzer diatur kecepatannya dengan menekan sampel dengan probe berbentuk silinder dengan diameter $35 \mathrm{~mm}$. Sampel diletakkan di bawah probe lalu mi basah ditekan dengan gaya tekan sesuai dengan pengaturan hingga terbaca tingkat kekenyalan dan kelengketannya dalam monitor di 
texture analyzer (Putra, 2008). Pengaturan texture analyzer disajikan pada Tabel 2.

\section{- Analisis kandungan vitamin $\mathbf{C}$}

Analisis kandungan vitamin $\mathrm{C}$ dilakukan pada mi basah yang menggunkan cabai merah sebagai pewarna alami. Seperti yang telah diketahui bahwa cabai mengandung berbagai senyawa antioksidan, salah satunya ialah asam askorbat atau yang lebih dikenal dengan vitamin C. Adanya vitamin C ini diharapkan akan tetap terkandung dalam mi basah yang sudah direbus. Metode yang dilakukan untuk mengetahui seberapa banyak kadar vitamin $\mathrm{C}$ dalam mi basah yang sudah direbus adalah melalui analisis HPLC atau High Performance Liquid Chromatography.

Preparasi sampel untuk dianalisis HPLC adalah sampel mi basah direbus selama 3-5 menit pada suhu $100^{\circ} \mathrm{C}$ lalu sampel ditiriskan, setelah ditiriskan, sampel dimaserasi terlebih dahulu, kemudian diekstraksi. Sampel yang sudah diestraksi selanjutnya disaring agar diperoleh filtratnya. Filtrat ekstrak sampel mi basah dilarutkan dengan eluen lalu diukur komponen vitamin C nya dengan HPLC (Saiya et al. 2017).

\section{HASIL DAN PEMBAHASAN}

Hasil pengujian mi basah dengan tanpa perlakuan, penambahan asam askorbat, asam sitrat, $\mathrm{Mg}(\mathrm{OH})_{2}$ dan $\mathrm{MgCO}_{3}$ disajikan pada Tabel 3. Setiap perlakuan memberikan pengaruh yang relatif saling berbeda pada kadar air, ketahanan warna, dan kekenyalan mi basah.

\section{Kadar Air (\%)}

Berdasarkan Tabel 3 diperoleh hasil bahwa perlakuan penambahan serbuk color retention agent

Tabel 2 Pengaturan Texture Analyzer dalam Metode TPA

\begin{tabular}{ll}
\hline \multicolumn{1}{c}{ Parameter } & \multicolumn{1}{c}{ Setting } \\
\hline Pre test speed & $2,0 \mathrm{~mm} / \mathrm{s}$ \\
Test speed & $0,1 \mathrm{~mm} / \mathrm{s}$ \\
Post test speed & $2,0 \mathrm{~mm} / \mathrm{s}$ \\
Rupture test speed & $1,0 \mathrm{~mm} / \mathrm{s}$ \\
Distance & $75 \%$ \\
Force & $100 \mathrm{~g}$ \\
Time & $5 \mathrm{sec}$ \\
Count & 2 \\
\hline
\end{tabular}

memberikan pengaruh yang signifikan $(p<0,05)$ pada kadar air mi basah. Mi basah pada perlakuan T0, T1, T2, T3, dan T4 menghasilkan kadar air yang lebih redah. Mi basah yang diwarnai dengan pewarna alami cabai merah tanpa penggunaan color retention agent (T0) memiliki kadar air yang paling tinggi, yaitu $33,87 \%$. Kadar air tertinggi pada mi basah tanpa penggunaan color retention agent (T0) dapat disebabkan oleh komposisi pada saat pembuatan. Mi basah T0 merupakan mi basah kontrol atau tanpa penambahan serbuk color retention agent. Kadar air tertinggi pada mi basah T0 dapat disebabkan oleh perbedaan rasio penambahan bahan padat dalam adonan $\mathrm{mi}$, yaitu hanya mi basah T0 yang tidak diberi penambahan color retention agent sebagai bahan padat tambahan. Didukung oleh pendapat Dewi (2010) yang menyatakan bahwa penambahan suatu zat yang memiliki kemampuan menyerap air bebas dalam suatu produk akan mengurangi kadar airnya. Sesuai dengan Tabel 2. bahwa mi basah T0 merupakan mi basah kontrol atau tanpa penambahan serbuk color retention agent sehingga jumlah air bebas dalam adonan mi basah T0 lebih besar karena tidak terdapat zat tambahan yang akan mengikatnya.

Serbuk color retention agents merupakan bahan kering yang memiliki sifat mampu menyerap dan larut dalam air. Menurut Anggraeni et al. (2013), penambahan bahan kering mampu menurunkan kadar air suatu produk karena bahan kering tersebut mampu menyerap air. Apabila serbuk atau granula color retention agent ditambahkan maka terdapat pula penambahan rasio bahan padat dalam mi basah. Tanpa adanya penambahan serbuk dari color retention agents akan menyebabkan semua air diserap oleh tepung terigu sehingga adonan T0 memiliki kadar air yang lebih tinggi. Kadar air mi basah yang tertinggi hingga terendah berturut-turut adalah mi basah T0, T3, T1, T2, kemudian T4. Kadar air mi basah T0, T1, T2, T3, dan T4, semuanya sesuai dengan SNI mi basah, yaitu kadar airnya tidak melebihi $35 \%$.

\section{Kekenyalan}

Berdasarkan Tabel 3 diperoleh hasil bahwa perlakuan penambahan color retention agent pada kekenyalan mi basah memberikan pengaruh yang signifikan. Menurut Rahma \& Sutrisno (2017), kekenyalan merupakan laju kemampuan suatu bahan pangan ke kondisi awal setelah diberi gaya tekanan

Tabel 3 Hasil pengujian kadar air dan kekenyalan mi basah

\begin{tabular}{lccccc}
\hline \multirow{2}{*}{ Parameter } & \multicolumn{5}{c}{ Perlakuan } \\
\cline { 2 - 6 } & $\mathrm{T} 0$ & $\mathrm{~T} 1$ & $\mathrm{~T} 2$ & $\mathrm{~T} 3$ \\
\hline Kadar air (\%) & $33,87 \pm 0,62^{\mathrm{b}}$ & $32,37 \pm 1,10^{\mathrm{a}}$ & $32,37 \pm 0,94^{\mathrm{a}}$ & $32,62 \pm 0,47^{\mathrm{a}}$ & $31,87 \pm 0,75^{\mathrm{a}}$ \\
Kekenyalan & $2,70 \pm 0,34^{\mathrm{a}}$ & $2,62 \pm 0,65^{\mathrm{a}}$ & $2,50 \pm 0,46^{\mathrm{a}}$ & $3,07 \pm 0,28^{\mathrm{b}}$ & $3,47 \pm 0,27^{\mathrm{b}}$ \\
\hline Keterangan:*Data & ditampilkan sebagai & nilai & rerata dari 4 & ulangan ${ }^{*}$ Superscript huruf kecil yang berbeda menunjukkan
\end{tabular}

Keterangan:*Data ditampilkan sebagai nilai rerata dari 4 ulangan, ${ }^{*}$ Superscript huruf kecil yang berbeda menunjukkan perbedaan nyata $(\mathrm{p}<0,05),{ }^{*}$ To $=\mathrm{mi}$ basah kontrol dengan pewarna alami cabai merah tanpa color retention agent; $\mathrm{T} 1$ = mi basah dengan pewarna alami cabai merah dengan penambahan asam askorbat sebagai color retention agent; $\mathrm{T} 2$ = mi basah dengan pewarna alami cabai merah dengan penambahan asam sitrat sebagai color retention agent; $\mathrm{T} 3=\mathrm{mi}$ basah dengan pewarna alami cabai merah dengan penambahan $\mathrm{Mg}(\mathrm{OH}) 2$ sebagai color retention agent; dan $\mathrm{T} 4=\mathrm{mi}$ basah dengan pewarna alami cabai merah dengan penambahan $\mathrm{MgCO} 3$ sebagai color retention agent. 
hingga sebelum produk tersebut hancur. Mi basah dengan tingkat kekenyalan tertinggi ke terendah ialah mi basah T4, T3, T0, T1 kemudian T2. Kekenyalan merupakan tekstur penting dalam penerimaa mi basah sebagai bahan olahan tepung terigu yang mengandung gluten. Menurut pendapat Daulay et al. (2018), pada dasarnya kekenyalan mi basah diperoleh dari komposisi gluten dan fraksi amilopektin tepung terigu yang berperan penting sebagai perekat komponen-komponen yang menguatkan ikatan molekul mi basah agar tidak mudah putus. Ditunjukkan pula melalui standar deviasi hasil statistik yang menyatakan bahwa kekenyalan mi basah T0, T1 dan T2 memiliki perbedaan nyata dengan kekenyalan mi basah T3 dan T4. Hal ini dapat disebabkan oleh sifat dan karakteristik setiap jenis color retention agent yang digunakan. Salah satu karakteristik yang mampu memengaruhi tingkat kekenyalan basah adalah nilai $\mathrm{pH}$. Hal ini didukung oleh pendapat Kusnadi et al. (2012) yang menyatakan bahwa nilai $\mathrm{pH}$ produk yang semakin tinggi akan semakin meningkatkan kekenyalannya. Oleh karena itu, mi basah dengan penambahan color retention agent yang bersifat asam memiliki kekenyalan yang lebih rendah. Tingkat kekenyalan paling tinggi terdapat pada mi basah T4 yaitu mi basah dengan penambahan color retention agent $\mathrm{MgCO}_{3}$.

\section{Ketahanan Warna}

Berdasarkan Gambar 1 dan Gambar 2 diperoleh hasil bahwa mi basah dengan derajat kecerahan paling tinggi ke rendah secara berturut-turut adalah T2, T3, $\mathrm{T} 4$, T1, dan T0, sedangkan mi basah dengan warna merah paling pekat hingga warna merah yang pudar secara berturut-turut adalah T4, T3, T1, T0, kemudian T2. Besarnya $\Delta L^{*}$ mi basah merupakan hasil dari pemudaran sebagian pigmen pewarna merah mi basah akibat suhu tinggi perebusan dan besar nilai $\Delta \mathrm{a}^{*}$ menggambarkan jumlah pigmen warna merah yang pudar akibat perebusan. Menurut Tedjautama \& Zubaidah (2014), kepekatan pigmen warna lain akan menurunkan derajat kecerahan suatu produk, mengingat derajat kecerahan adalah spectrum warna dasar, begitu pula sebaliknya bahwa derajat kecerahan

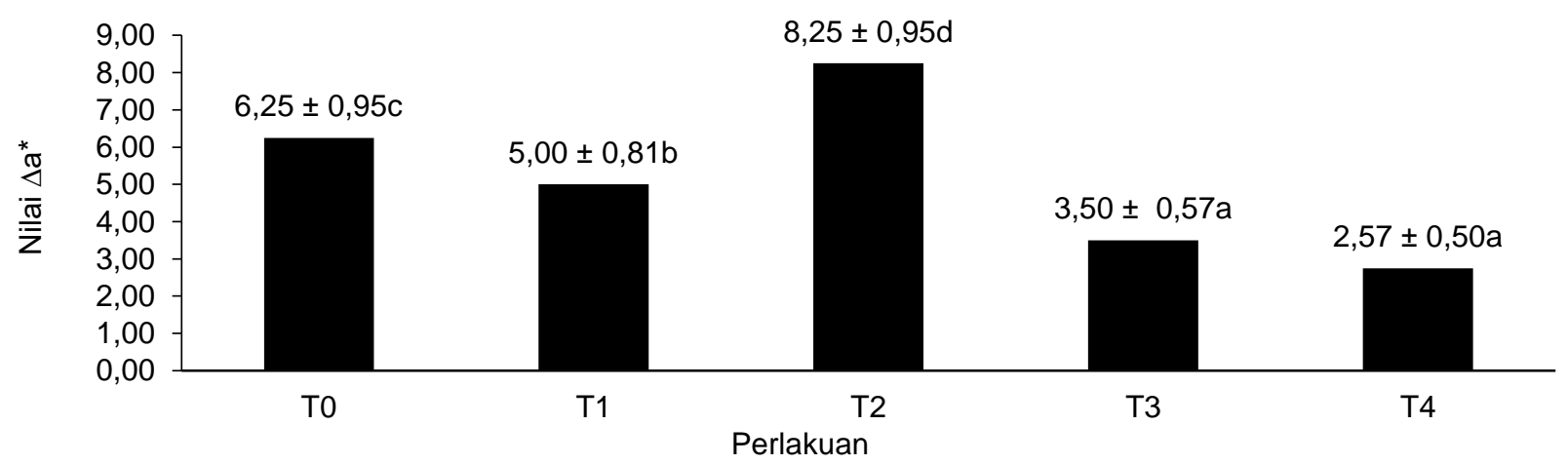

Gambar 1 Nilai $\Delta a^{*}$ mi basah. *Data ditampilkan sebagai nilai rerata dari 4 ulangan. *Superscript huruf kecil yang berbeda menunjukkan perbedaan nyata $(\mathrm{p}<0,05) .{ }^{*}$ To $=$ mi basah kontrol dengan pewarna alami cabai merah tanpa color retention agent; $\mathrm{T} 1$ = mi basah dengan pewarna alami cabai merah dengan penambahan asam askorbat sebagai color retention agent; $\mathrm{T} 2=\mathrm{mi}$ basah dengan pewarna alami cabai merah dengan penambahan asam sitrat sebagai color retention agent; T3 = mi basah dengan pewarna alami cabai merah dengan penambahan $\mathrm{Mg}(\mathrm{OH}) 2$ sebagai color retention agent; dan T4 = mi basah dengan pewarna alami cabai merah dengan penambahan $\mathrm{MgCO} 3$ sebagai color retention agent.

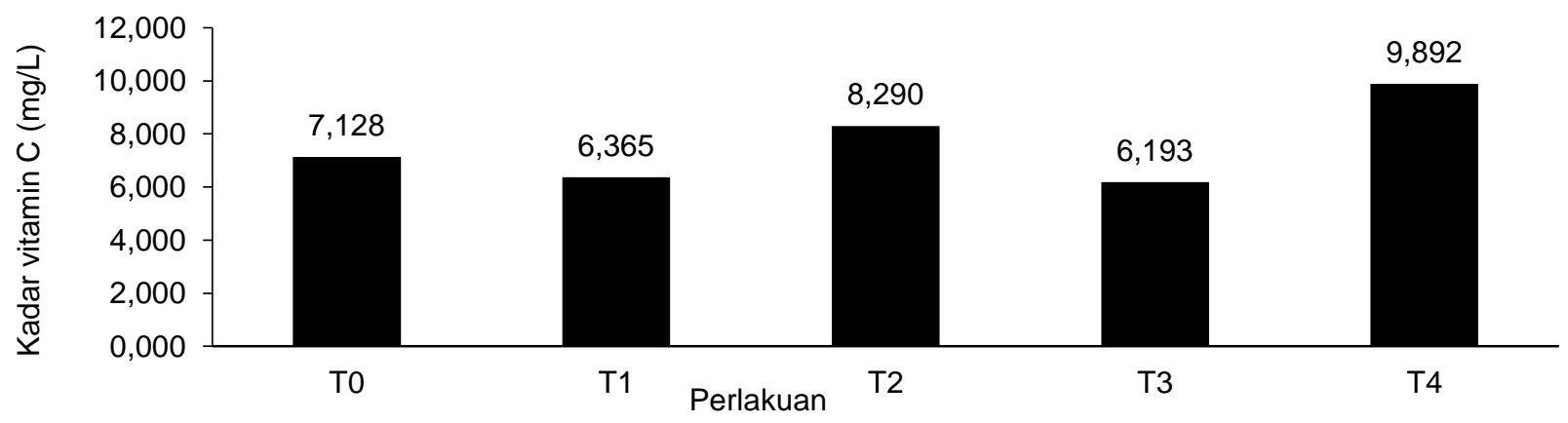

Gambar 2 Nilai $\Delta \mathrm{L}^{*}$ mi basar. *Data ditampilkan sebagai nilai rerata dari 4 ulangan. *Superscript huruf kecil yang berbeda menunjukkan perbedaan nyata $(p<0,05)$. ${ }^{*}$ To $=$ mi basah kontrol dengan pewarna alami cabai merah tanpa color retention agent; $\mathrm{T} 1$ = mi basah dengan pewarna alami cabai merah dengan penambahan asam askorbat sebagai color retention agent; $\mathrm{T} 2$ = mi basah dengan pewarna alami cabai merah dengan penambahan asam sitrat sebagai color retention agent; $\mathrm{T} 3=$ mi basah dengan pewarna alami cabai merah dengan penambahan $\mathrm{Mg}(\mathrm{OH}) 2$ sebagai color retention agent; dan T4 = mi basah dengan pewarna alami cabai merah dengan penambahan MgCO3 sebagai color retention agent. 
akan meningkat apabila intensitas pigmen warna lain (nilai $\left.a^{\star}\right)$ menurun.

Hasil analisis statistik menunjukkan adanya pengaruh signifikan penambahan color retention agent pada ketahanan warna mi basah. Perbedaan warna yang dihasilkan merupakan perbedaan kemampuan masing-masing color retention agent. Terdapat berbagai faktor yang memengaruhi kemampuan masingmasing color retention agent, seperti karakteristik kimia, nilai $\mathrm{pH}$, kemampuan antioksidannya, serta faktor eksternal lainnya, seperti suhu, cahaya, dan udara lingkungan. Sesuai dengan pendapat Wahyuni \& Widjanarko (2015) yang menyatakan bahwa pada umumnya pigmen karotenoid stabil dalam kondisi $\mathrm{pH}$ netral dan basa. Warna merah cabai berasal dari pigmen karotenoid. Selama proses perebusan, pigmen akan terdegradasi karena panas, oleh karena itu dibutuhkan peran color retention agent untuk mampu mempertahankan pigmen karotenoid. Didukung oleh pendapat Fajar et al. (2014) yang menyatakan bahwa semakin tinggi suhu pengolahan maka kandungan pigmen karotenoid semakin menurun akibat isomerisasi dan oksidasi baik enzimatik maupun nonenzimatik yang menyebabkan kerusakan ikatan konjugasi pigmen sehingga warna merah pudar dan nilai kecerahan meningkat. Kesimpulan yang dapat diperoleh dari pengamatan ini ialah mi basah dengan warna merah paling pekat adalah mi basah T4 sehingga color retention agent yang paling mampu mempertahankan warna merah ialah $\mathrm{MgCO}_{3}$. Kesimpulan ini diperoleh dari nilai $\Delta a^{*}$ yang paling rendah di antara keempat perlakuan, nilai $\Delta \mathrm{a}^{*}$ mi basah T4 adalah 2,00. Sementara itu, mi basah dengan tingkat kepudaran warna merah yang paling tinggi ialah mi basah T2 karena memiliki nilai $\Delta L^{*}$ yang paling tinggi, yaitu sebesar 22,00.

Hasil pengujian kadar air mi basah dengan tanpa perlakuan, penambahan asam askorbat, asam sitrat, $\mathrm{Mg}(\mathrm{OH})_{2}$, dan $\mathrm{MgCO}_{3}$ disajikan pada Tabel 3. Tidak terdapat perbedaan yang signifikan antara jenis perlakuan pada profil tekstur kelengketan mi basah.

\section{Kelengketan}

Berdasarkan Tabel 4 diperoleh hasil bahwa tidak terdapat perbedaan yang signifikan $(p>0,05)$ antara penambahan colour retention agent dalam mi basah dengan pewarna cabai pada kelengketan mi basah. Tingkat kelengketan mi basah berbanding terbalik dengan tingkat kekenyalannya. Mi basah yang paling kenyal adalah mi basah T4 kemudian mi basah yang paling lengket adalah mi basah T0. Kelengketan ini merupakan kecenderungan suatu bahan menempel dengan bahan yang lain. Didukung oleh pendapat Ratnawati \& Afifah (2018) yang menyatakan bahwa kelengketan atau adhesiveness merupakan sifat reologi yang terjadi pada saat terjadi gaya tarik menarik antara permukaan bahan pangan dengan permukaan bahan lainnya pada saat bersentuhan. Kelengketan mi basah ini dapat dipengaruhi oleh kadar airnya. Didukung oleh pendapat Noriandita et al. (2013) yang menyatakan bahwa semakin tinggi kadar air maka gugus hidroksil pati semakin mampu menyerap air, namun kadar air yang lebih banyak akan menyebabkan tekstur lebih lengket. Sesuai dengan hasil analisis, yaitu mi basah TO memiliki tekstur yang paling lengket.

\section{Kandungan Vitamin C}

Berdasarkan data yang disajikan dalam Gambar 3 diperoleh hasil bahwa mi basah dengan kandungan vitamin $\mathrm{C}$ tertinggi hingga terendah secara berturutturut adalah mi basah T4, T2, T1, T0 kemudian T3. Mi basah T4 merupakan perlakuan terbaik dalam mempertahankan kandungan vitamin $\mathrm{C}$ dibandingkan dengan $\mathrm{mi}$ basah perlakuan lainnya. $\mathrm{Hal}$ ini bertentangan dengan pendapat Rahayu \& Pribadi (2012) yang menyatakan bahwa vitamin $C$ cenderung stabil dalam kondisi asam dan tidak stabil pada kondisi netral atau basa. Akan tetapi, terdapat ketidaksesuaian teori dengan data yang diperoleh bahwa magnesium karbonat mampu menstabilkan $\mathrm{pH}$ mi basah sesuai dengan kondisi vitamin C meski dalam proses pengolahan. Ketidaksesuaian ini dapat disebabkan oleh aktivitas $\mathrm{MgCO}_{3}$ sebagai senyawa garam dalam pengolahan $\mathrm{mi}$ basah dengan sari cabai. $\mathrm{MgCO}_{3}$ merupakan garam anorgaik yang mampu melindungi kestabilan senyawa antioksidan mi basah. Hal ini didukung oleh pendapat Lee et al. (1989) yang menyatakan bahwa penambahan garam, seperti sodium hidroksida, sodium karbonat, magnesium karbonat, dan potasium fosfat merupakan senyawa buffer yang mampu menstabilkan nilai $\mathrm{pH} . \mathrm{MgCO}_{3}$ membentuk ikatan yang mampu mengkelat zat-zat logam yang mampu mengoksidasi vitamin $\mathrm{C}$.

Perlakuan terbaik yang mempertahankan kandungan vitamin $\mathrm{C}$ mi basah setelah mi basah T4 ialah mi basah T2, yang mengalami penambahan asam sitrat. Asam sitrat merupakan antioksidan yang mampu mencegah proses oksidasi oleh radikal bebas. Didukung oleh pendapat Indasah (2012) yang me-

Tabel 4 Hasil analisis kelengketan mi basah

\begin{tabular}{|c|c|c|c|c|}
\hline \multirow{2}{*}{ Parameter } & \multicolumn{4}{|c|}{ Perlakuan } \\
\hline & T0 & $\mathrm{T} 1$ & T2 & $\mathrm{T} 4$ \\
\hline Kelengketan & $0,1250 \pm 0,000^{a}$ & $0,0325 \pm 0,020^{a}$ & $0,0325 \pm 0,005^{a}$ & $0,0175 \pm 0,009^{a}$ \\
\hline \multicolumn{5}{|c|}{$\begin{array}{r}\text { Keterangan: }{ }^{*} \text { Data ditampilkan sebagai nilai rerata dari } 4 \text { ulangan, }{ }^{*} \text { Superscript huruf kecil yang berbeda menunjukkan tidak } \\
\text { terdapat perbedaan nyata }(p>0,05),{ }^{*} \mathrm{To}=\mathrm{mi} \text { basah kontrol dengan pewarna alami cabai merah tanpa color } \\
\text { retention agent; } \mathrm{T} 1=\mathrm{mi} \text { basah dengan pewarna alami cabai merah dengan penambahan asam askorbat sebagai } \\
\text { color retention agent; } \mathrm{T} 2=\text { mi basah dengan pewarna alami cabai merah dengan penambahan asam sitrat } \\
\text { sebagai color retention agent; } \mathrm{T} 3=\text { mi basah dengan pewarna alami cabai merah dengan penambahan } \mathrm{Mg}(\mathrm{OH}) 2 \\
\text { sebagai color retention agent; dan } \mathrm{T} 4=\text { mi basah dengan pewarna alami cabai merah dengan penambahan } \\
\text { MgCO3 sebagai color retention agent. }\end{array}$} \\
\hline
\end{tabular}




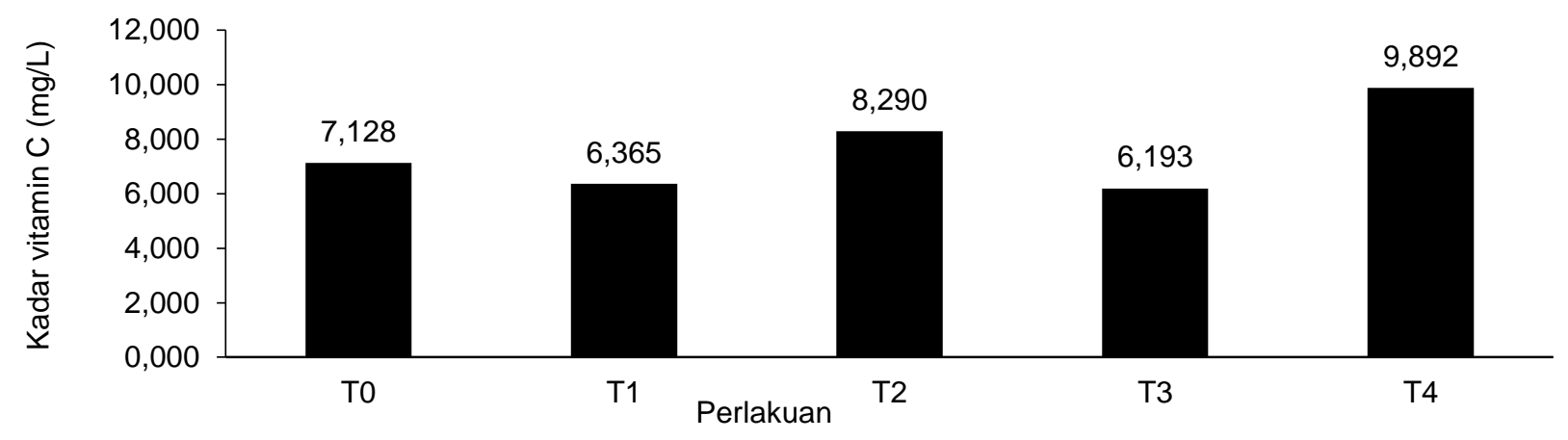

Gambar 3 Kandungan vitamin C mi basah. *Data ditampilkan sebagai nilai rerata dari 4 ulangan. *Superscript huruf kecil yang berbeda menunjukkan perbedaan nyata $(p<0,05) .{ }^{*}$ To $=$ mi basah kontrol dengan pewarna alami cabai merah tanpa color retention agent; $\mathrm{T} 1=\mathrm{mi}$ basah dengan pewarna alami cabai merah dengan penambahan asam askorbat sebagai color retention agent; T2 = mi basah dengan pewarna alami cabai merah dengan penambahan asam sitrat sebagai color retention agent; T3 = mi basah dengan pewarna alami cabai merah dengan penambahan $\mathrm{Mg}(\mathrm{OH}) 2$ sebagai color retention agent; dan T4 = mi basah dengan pewarna alami cabai merah dengan penambahan $\mathrm{MgCO} 3$ sebagai color retention agent.

nyatakan bahwa asam sitrat merupakan antioksidan yang mekanismenya mengikat ion-ion logam yang mampu mengoksidasi karena memiliki 4 pasang elektron bebas pada gugus karboksilat yang diberikan pada ion logam sehingga terbentuk senyawa kompleks. Bahkan, kemampuan asam sitrat dalam mempertahankan vitamin $\mathrm{C}$ atau asam askorbat lebih baik daripada kemampuan color retention agent asam askorbat itu sendiri. Kurang mampunya color retention agent asam askorbat mempertahankan kandungan asam askorbat yang secara alami terkandung dalam sari cabai, dapat disebabkan oleh sifatnya yang sangat labil terdegradasi. Hal ini didukung oleh pendapat Pusung et al. (2016) yang menyatakan bahwa asam askorbat adalah senyawa yang sangat peka terhadap oksidasi enzimatik oleh asam askorbat oksidase yang sudah terdapat dalam tanaman cabe itu sendiri. Menurut Rahayu \& Pribadi (2012) vitamin C dapat teroksidasi secara spontan dan tidak spontan. Oksidasi tidak spontan ini dapat terjadi akibat paparan udara, asam askorbat juga sangat mudah terdegradasi oleh paparan cahaya, temperatur, serta mudah larut dalam air sehingga asam askorbat sangat mudah hilang sejak proses penanganan cabai merah sebagai pewarna, terlebih pada saat mengalami pemanasan dengan suhu tinggi.

Berbeda dari mi basah T4, mi basah T3 justru tidak mampu mencegah kehilangan vitamin $\mathrm{C}$ mi basah. Karakteristik $\mathrm{Mg}(\mathrm{OH})_{2}$ sebagai color retention agent terbukti kurang mampu mencegah oksidasi vitamin $\mathrm{C}$ dalam mi basah, bahkan $\mathrm{mi}$ basah TO masih mengandung vitamin $\mathrm{C}$ dengan kadar yang lebih banyak. Color retention agent $\mathrm{Mg}(\mathrm{OH})_{2}$ merupakan senyawa basa kuat. Didukung oleh pendapat Laili et al. (2017) yang menyatakan bahwa dalam suasana basa, cincin lakton asam dehidroaskorbat tidak dapat terurai sehingga akan menghilangkan vitamin $\mathrm{C}$ karena tidak mampu membentuk senyawa diketoglutanat yang dapat melindungi vitamin C. Vitamin C mudah terdegradasi pula dalam suasana basa. Penurunan kandungan vitamin $\mathrm{C}$ dalam mi basah T3 juga dapat disebabkan oleh kandungan asam askorbat dalam mi yang secara spontan teroksidasi karena kondisi lingkungan. Sesuai dengan pendapat Robiati (2011) yang menyatakan bahwa asam askorbat dalam wujud kristal sangat stabil dengan udara, namun untuk asam askorbat yang terlarut dalam air akan mudah teroksidasi oleh udara yang kemudian terdekomposisi menjadi DAA atau dehydro-ascoric acid. Selain itu, mi basah telah mengalami proses pemanasan melalui perebusan sehingga semakin menurunkan kandungan vitamin C. Penambahan color retention agent dalam mi basah ini memberikan pengaruh pada kandungan vitamin $\mathrm{C}$, di mana mi basah $\mathrm{T} 4$ adalah mi basah yang paling banyak kandungan vitamin Cnya.

\section{KESIMPULAN}

Perlakuan penambahan color retention agent pada mi basah dengan pewarna alami dari cabai memberikan pengaruh yang nyata pada ketahanan warna, kadar air, tekstur, dan kandungan vitamin C mi basah. Mi basah T4 merupakan mi basah perlakuan terbaik karena kemampuannya mempertahankan warna merah dan kandungan vitamin $\mathrm{C}$, memiliki kadar air, kekenyalan, dan kelengketan yang baik.

\section{DAFTAR PUSTAKA}

Anggraini RP, Rahardjo AHD, Santosa R. 2013. Pengaruh level enzim bromelin dari nanas masak dalam pembuatan tahu susu terhadap rendemen dan kekenyalan tahu susu. Jurnal IImiah Peternakan. 1(2): 1-10.

[AOAC] Association of Official Analytcal Chemists. 2005. Official Methods of Analysis. Association of Official Analiytical Chemistry, Washington DC (US). 
Bahri S. 2012. Proses Produksi Mi Cabai Basah "SAFIRA" Kaya Akan Vitamin C. Program Studi Diploma III Teknologi Hasil Pertanian Fakultas Pertanian Universitas Sebelas Maret, Surakarta (ID): (Tugas Akhir Diploma III Teknologi Hasil Pertanian).

Daulay AH, Yusmarini Y, Zalfiatri Y. 2018. Pemanfaatan tepung ubi jalar ungu dan tepung kelapa sebagai bahan pensubstitusi terigu dalam pembuatan mi instan. Jurnal Sagu. 17(2): 18-27.

Engelen A. 2017. Karakteristik kekerasan dan kelengketan pada pembuatan $\mathrm{mi}$ sagu basah. Journal of Agritech. 1(2): 4-67.

Fajar A, Ibrahim R. Dwi EN. 2014. Stabilitas ekstrak kasar pigmen klorofil, beta karoten dan caulerpin alga hijau (Caulerpa racemosa) pada suhu penyimpanan yang berbeda. Jurnal Pengolaha dan Bioteknologi Hasil Perikanan. 3(1): 1-10.

Indasah. 2012. Dampak penambahan chelating agent (asam asetat, asam sitrat dan jeruk nipis) terhadap kadar $\mathrm{Fe}, \mathrm{Zn}$ dan protein daging kupang beras (Corbua faba). Jurnal Imiah Kesehatan. 1(1): 3748.

Kusnadi DC, Bintoro VP, AI-Baarri AN. 2012. Daya ikat air, tingkat kekenyalan dan kadar proteoin pada baks kombinasi daging sapi dan daging kelinci. Jurnal Aplikasi Teknologi Pangan. 1(2): 28-31.

Laili M, Alimuddin, Erwin. 2017. Penetapan kadar vitamin c dalam sirup buah naga merah (Hylocereus polyrhizus) dengan variasi waktu penyimpanan. Jurnal Atomik. 2(1): 128-133.

Lee Y, Merritt CG, Dermody NE. 1989. Method of preserving color of vegetable pasta products. U.S. Patent and Trademark Office.

Manurung M. 2012. Aplikasi kulit buah manggis (Garcinia mangostana L.) sebagai pewarna alami pada kain katun secara pre-mordanting. Jurnal Kimia. 6(2): 183-190.

Noriandita B, Ummah S, Purwandari U, Maflahah I, Sidik RF. 2013. Sifat Tekstural dan Anaisis Sensori Mi Bebas Glten dari Tepung Porang sebagai Efek Pregelatinisasi. Seminar Nasional: Menggagas Kebangkitan Komoditas Unggulan Lokal Pertanian dan Kelautan Fakultas Pertanian Universitas Trunojoyo Madura. Madura (ID).

Oktiarni D, Ratnawati D, Anggraini DZ. 2012. Pemanfaatan ekstrak kulit buah naga merah (Hylocereus polyrhizus sp.). Jurnal Gradien. 8(2): 819-824.

Pusung WA, Abram PH, Gonggo ST. 2016. Uji efektivitas ekstrak daun sambiloto ( $A$. paniculata (burm.f nees) sebagai pengawet alami tomat dan cabai merah. Jurnal Akademika Kimia. 5(3): 146152. https://doi.org/10.22487/j24775185.2016. v5.i3.8049

Putra SN. 2008. Optimalisasi Formula dan Proses Pembuatan $\mathrm{Mi}$ Jagung dengan Metode Kalendering. Skripsi Departemen IImu dan Teknologi Pangan Fakultas Teknologi Pertanian Institut Pertanian Bogor. Bogor (ID).

Rahayu ES, Pribadi P. 2012. Kadar vitamin dan mineral dalam buah segar dan manisan basah karika dieng (Carica pubescus lenne \& K. Koch). Jurnal Biosantifika. 4(2): 89-97.

Rahma P, Sutrisno A. 2017. Sosis analog berbasis tempe kedelai hitam (Glysine soja) (perbedaan persentase gel glukomanan dan jenis pati). Jurnal Pangan dan Agroindustri. 5(2): 74-84.

Robiati S. 2011. Pengaruh Konsentrasi Asam Askorbat (Vitamin C) sebagai Inhibitor Korosi pada Baja yang Mengandung Klorida Menggunakan Metode Immersi. [Dissertasi]. Universitas Isalam Negeri Sultan Syarif Kasim Riau. Riau (ID).

Saiya AD, Gumolung, Howan DHO. 2017. Analisis residu klorpirifos dalam sayuran kubis dengan metode hplc di beberapa pasar tradisional di sulawesi utara. Jurnal Eksakta. 18(2): 1-9. https:// doi.org/10.24036/eksakta/vol18-iss02/57

Standar Nasional Indonesia SNI. 1992. SNI. 01-29871992. Mi Basah. Badan Standardisasi Nasional, Jakarta (ID).

Sumardana G, Syam H, Sukainah A. 2017. Substitusi tepung bonggol pisang pada mi basah dengan penambahan kulit buah naga (Hylocereus undatus). Jurnal Pendidikan Teknologi Pertanian. 3: 145-157. https://doi.org/10.26858/jptp.v3i0.5714

Ratnawati L, Afifah N. 2018. Pengaruh penggunaan guar gum, carboxymethylcellulose (cmc) dan karagenan terhadap kualitas mi yang terbuat dari campuran mocaf, tepung beras dan tepung jagung. Jurnal Pangan. 27(1): 43-54.

Tedjautama E, Zubaidah E. 2014. Peningkatan produksi pigmen merah angkak tinggi lovastan menggunakan ko-kultur Monascus puspureus dan Saccaromyces cerevisiae. Jurnal Pangan dan Agroindustri. 2(4): 78-88.

Wahyuni DT, Widjanarko SD. Pengaruh jenis pelarut dan lama ekstraksi terhadap karotenoid labunkuning dengan metode gelombang ultrasonik. Jurnal Pangan dan Agroindustri. 3(2): 390-401. 